\title{
Digestion, Ruminal Fermentation, Ciliate Protozoal Populations, and Milk Production from Dairy Cows Fed Cinnamaldehyde, Quebracho Condensed Tannin, or Yucca schidigera Saponin Extracts ${ }^{1}$
}

\author{
C. Benchaar, ${ }^{\star 2}$ T. A. McAllister, $†$ and P. Y. Chouinard‡ \\ ${ }^{*}$ Agriculture and Agri-Food Canada, Dairy and Swine Research and Development Centre, Sherbrooke, Québec, Canada J1M 1 Z3 \\ †Agriculture and Agri-Food Canada, Lethbridge Research Centre, Lethbridge, Alberta, Canada T1J 4B1 \\ ‡Département des Sciences Animales, Université Laval, Québec, Québec, Canada G1V 0A6
}

\begin{abstract}
Four ruminally cannulated lactating cows were used in a $4 \times 4$ Latin square design (28-d periods) to determine the effects of cinnamaldehyde (CIN; $1 \mathrm{~g} /$ cow per day), condensed tannins from quebracho trees (QCT, containing $70 \%$ tannins, $150 \mathrm{~g} / \mathrm{cow}$ per day), and saponins from Yucca schidigera extract (YSE, containing $10 \%$ saponins; $60 \mathrm{~g} / \mathrm{cow}$ per day) on digestion, ruminal fermentation characteristics, protozoal populations, and milk production. Intake of dry matter was not affected by the addition of CIN or QCT, but cows fed YSE had lesser intake than cows fed the control diet (21.8 vs. $23.2 \mathrm{~kg} / \mathrm{d})$. Apparent total-tract digestibilities of dry matter, organic matter, crude protein, neutral detergent fiber, and acid detergent fiber were unaffected by dietary treatments. Supplementation with CIN, QTE, or YSE did not affect in situ ruminal degradation of soybean meal, grass silage, or corn grain. Ruminal $\mathrm{pH}$ (6.67), total volatile fatty acid concentration $(135 \mathrm{mM})$, and molar proportions $(\mathrm{mol} / 100 \mathrm{~mol}$ of total volatile fatty acid) of acetate (65.0), propionate (19.6), and butyrate (11.2) were similar among treatments. Ruminal $\mathrm{NH}_{3}-\mathrm{N}$ concentration was not changed by the addition of CIN and YSE, but tended to decrease in cows fed QCT compared with cows fed the control diet (132 vs. $160 \mathrm{mg} / \mathrm{L}$ ). Total numbers of ruminal protozoa were not changed by adding CIN, QCT, or YSE in the diet $\left(5.85 \log _{10} / \mathrm{mL}\right)$. However, the number of Isotricha was greater in ruminal fluid of cows fed CIN than in ruminal fluid of cows fed the control diet (4.46 vs. $\left.4.23 \log _{10} / \mathrm{mL}\right)$. Milk production $(33.1 \mathrm{~kg} / \mathrm{d})$, milk fat $(4.3 \%)$, and milk protein (3.5\%) remained unchanged between dietary treatments. Results of this study show that under our experimental conditions, supplementing
\end{abstract}

Received May 7, 2008.

Accepted August 8, 2008.

${ }^{1}$ Contribution number 965 from the Dairy and Swine Research and Development Centre, PO Box 90, STN-Lennoxville, Sherbrooke, Québec, Canada J1M 1Z3.

${ }^{2}$ Corresponding author: benchaarc@agr.gc.ca dairy cow diets with CIN, QCT, or YSE had limited effects on digestion, ruminal fermentation characteristics, and protozoal populations. The lack of effects observed in this study suggests that these antimicrobials require administration at greater doses to favorably alter rumen microbial fermentation.

Key words: dairy cow, plant extract, rumen fermentation, in vivo

\section{INTRODUCTION}

In recent years, much research has focused on evaluating the potential use of plant extracts as alternatives to feed antibiotics to improve feed efficiency in ruminants. Plants produce an array of diverse secondary metabolites that when extracted and concentrated may exert antimicrobial activities against rumen microbes (Benchaar et al., 2008). Plant secondary metabolites such as saponins and tannins (hydrolyzable and condensed) have been extensively assessed for their antimicrobial effects and their potential to modulate ruminal fermentation and improve nutrient utilization in ruminants (Benchaar et al., 2007c). In contrast, information on essential oils is limited, but recent reviews in this area (Calsamiglia et al., 2007; Benchaar et al., 2008) described the potential of some essential oils to favorably modify rumen microbial fermentation. However, most of the studies published to date have been laboratory-based (i.e., in vitro) and of short-term nature (Busquet et al., 2006; Benchaar et al., 2007a; Fraser et al., 2007; Hristov et al., 2008). Extrapolation of results from in vitro experiments to in vivo conditions has limitations. Although in vitro experiments have been useful in screening several essential oils and their components for their antimicrobial activity and predicting adequate concentrations, the ultimate value of these plant extracts for altering rumen microbial fermentation must be assessed in vivo. In fact, results from in vitro batch culture studies must be interpreted with caution because they report effects over a set incubation time (24 or $48 \mathrm{~h}$ ) and do not account for the possible 
adaptation of rumen microbes to plant extracts. On the other hand, with the exception of the study of Fraser et al. (2007) results from other continuous culture studies were obtained at constant $\mathrm{pH}$, which is useful to isolate $\mathrm{pH}$ effects but is not representative of actual ruminal $\mathrm{pH}$ conditions (i.e., postprandial changes, influence of $\mathrm{pH}$ on substrate degradation, and fermentation pattern) occurring in the animal.

Few studies have investigated the effects of essential oils and their components on feed intake, digestion, ruminal fermentation, and milk performance of dairy cows (Benchaar et al., 2006b, 2007b; Yang et al., 2007). Moreover, to our knowledge, no study has examined in the same experiment the effects of essential oils and those of other plant extracts on digestion, ruminal fermentation, and milk production of dairy cows.

We hypothesized that at the selected dietary concentrations used in the current study, feeding cinnamaldehyde (CIN; main component of cinnamon essential oil, Cinnamomum cassia), condensed tannins from quebracho trees (QCT; Schinopsis balansae), or Yucca schidigera saponin extracts (YSE) to dairy cows will favorably modify rumen microbial fermentation without adversely affecting feed intake and nutrient digestion. Therefore, the objective of this study was to determine the effects of these plant extracts on feed intake, ruminal fermentation characteristics, protozoal populations, and milk production.

\section{MATERIALS AND METHODS}

\section{Cows, Experimental Design, and Treatments}

Four lactating Holstein cows fitted with ruminal cannulas $(10 \mathrm{~cm}$, Bar Diamond Inc., Parma, ID) were used in a $4 \times 4$ Latin square design (28-d periods) balanced for carryover effects. The cows averaged $87 \pm 29$ DIM at the start of the experiment with an average BW of $730 \pm 89 \mathrm{~kg}$. They were housed in individual tie stalls and had free access to water during the experiment. Cows were fed for ad libitum intake (5 to $10 \%$ orts, on as-fed basis) a TMR (Table 1) without supplementation (control), or supplemented with CIN $(1 \mathrm{~g} / \mathrm{d})$, QCT $\left(150 \mathrm{~g} / \mathrm{d}\right.$, ), or YSE $(60 \mathrm{~g} / \mathrm{d})$. Cinnamaldehyde $\left(\mathrm{C}_{9} \mathrm{H}_{8} \mathrm{O}\right.$, 98\% purity) was provided by Phodé SA (Albi, France), quebracho extract (containing $70 \%$ of condensed tannins) by Unitan (Buenos Aires, Argentina), and Yucca schidigera extract (DK sarasponin 30, containing 10\% of steroidal saponins) by Desert King International (San Diego, CA). The appropriate amount of CIN, QCT, and YSE for each cow was weighed daily and mixed thoroughly into a portion of the TMR to ensure the consumption of the entire dose. Adaptation to experimental treatments was from d 1 to 15 , in situ
Table 1. Ingredients and chemical composition of the TMR

\begin{tabular}{lc}
\hline Item & \% of DM \\
\hline Ingredient & \\
Grass silage & 39.6 \\
Corn, ground & 15.9 \\
Beet pulp, dehydrated & 12.0 \\
Corn gluten meal & 9.9 \\
Wheat bran & 9.8 \\
Soybean meal, 48\% CP & 8.8 \\
Sodium bicarbonate & 1.5 \\
Limestone & 1.1 \\
Ca 17\%: P 21\% & 0.6 \\
Salt ${ }^{1}$ & 0.4 \\
Magnesium oxide & 0.3 \\
Vitamin A, D, and E premix ${ }^{2}$ & 0.2 \\
Selenium & 0.04 \\
Chemical composition & \\
DM, \% & 53.9 \\
OM, \% of DM & 89.5 \\
CP, \% of DM & 18.2 \\
NDF, \% of DM & 43.2 \\
ADF, \% of DM & 24.1 \\
\hline
\end{tabular}

${ }^{1}$ Contained (per kg): $965 \mathrm{~g}$ of $\mathrm{NaCl} ; 7,500 \mathrm{mg}$ of $\mathrm{Zn} ; 5,000 \mathrm{mg}$ of $\mathrm{Mn}$; 2,500 $\mathrm{mg}$ of $\mathrm{Cu} ; 1,600 \mathrm{mg}$ of Fe; $70 \mathrm{mg}$ of I; and $40 \mathrm{mg}$ of Co.

${ }^{2}$ Contained (per kg): 500,000 IU of vitamin A; 50,000 IU of vitamin D, and $550 \mathrm{IU}$ of vitamin $\mathrm{E}$.

ruminal degradability measurements from d 16 to 17 , ruminal sampling on d 20, fecal sampling on d 21 to 25 , and milk yield and sampling from d 21 to 28 . Cows were cared for in accordance with the guidelines of the Canadian Council on Animal Care (CCAC, 1993).

\section{Feed Intake and Apparent Total-Tract Digestibility}

Diets were offered in equal amounts twice daily (0800 and $1600 \mathrm{~h}$ ). Feed consumption was recorded daily by weighing feeds offered to and refused by the cows. Samples of the TMR, feed ingredients, and orts were collected daily and kept frozen. Samples were composited by period, dried at $55^{\circ} \mathrm{C}$ for $48 \mathrm{~h}$, ground through a 1-mm screen Wiley mill (standard model 4; Arthur M. Thomas, Philadelphia, PA) and analyzed for DM, OM, total N, NDF, and ADF.

Apparent total-tract digestibility of nutrients was determined using $\mathrm{Cr}_{2} \mathrm{O}_{3}$ as an external marker contained in pelleted concentrates. The cows were fed once daily $250 \mathrm{~g}$ of pellets containing $10 \mathrm{~g}$ of $\mathrm{Cr}_{2} \mathrm{O}_{3}$ for $10 \mathrm{~d}$ starting $5 \mathrm{~d}$ before fecal collections began. In all cases, the entire marker dose was consumed. Fecal samples (100 $\mathrm{g}$ of wet weight) were collected twice daily at 0900 and $1600 \mathrm{~h}$ from the rectum of each cow on 5 consecutive days. The samples were composited by cow and period and immediately frozen $\left(-20^{\circ} \mathrm{C}\right)$. The pooled samples were subsequently dried at $55^{\circ} \mathrm{C}$ for $48 \mathrm{~h}$ in a forcedair oven, ground through a 1-mm screen, and analyzed for analytical DM, total N, OM, NDF, ADF, and Cr. 
The apparent digestibility of DM was calculated as follows: DM digestibility $=(1-\{[\mathrm{Cr}$ fed $(\mathrm{mg} / \mathrm{d})] /[\mathrm{DMI}$ $(\mathrm{kg} / \mathrm{d}) \times \mathrm{Cr}$ in feces $(\mathrm{mg} / \mathrm{kg}$ of DM) $]\}) \times 100$, where DMI represents DMI consumed during the 5-d fecal collection period. Digestibility of OM, CP, NDF, and $\mathrm{ADF}$ was calculated using the same approach with the corresponding intake for each nutrient.

\section{In Situ Ruminal Degradability}

Ruminal degradabilities of soybean meal, grass silage, or corn grain were determined using the nylon bag procedure. Feeds were freeze-dried, ground through a 2-mm screen in a Wiley mill (standard model 4; Arthur H. Thomas, Philadelphia, PA), and 5-g samples (DM basis) were weighed in duplicate in polyester bags $(17 \mathrm{~cm}$ $\times 9 \mathrm{~cm} ; 53 \mu \mathrm{m}$ pore size) made of monofilament PeCAP Polyester (B. \& S. H. Thompson, Ville Mont-Royal, Québec, Canada). Bags were placed in large mesh (20 $\mathrm{cm} \times 30 \mathrm{~cm})$ retaining sacs with 3 - $\mathrm{mm} \times 5-\mathrm{mm}$ pores that allowed ruminal fluid to circulate freely. Bags were soaked in $37^{\circ} \mathrm{C}$ water for 5 min before being placed in duplicates in the ventral sac of the rumen for $0,2,4,8$, 16, 24, and $48 \mathrm{~h}$ (soybean meal); 0, 2, 4, 8, 16, 24, and $48 \mathrm{~h}$ (corn grain); and $0,2,4,8,16,24,48,72$, and 96 $\mathrm{h}$ (grass silage). Upon removal from the rumen, bags were immediately immersed in ice water to impede microbial activity, then thoroughly rinsed with cold tap water and frozen at $-20^{\circ} \mathrm{C}$. Afterward, bags were thawed, washed in a domestic washing machine, and dried at $55^{\circ} \mathrm{C}$ for $48 \mathrm{~h}$. Bags and contents were weighed, and dried residues were ground through a 1-mm screen (1093 Cyclotec Sample Mill, Höganäs, Sweden) and stored for subsequent analysis of DM (soybean meal, grass silage, and corn grain), total N (soybean meal), NDF, and ADF (grass silage). Zero-time disappearance was obtained by washing unincubated bags in a similar manner.

Kinetics of ruminal degradation of DM, CP, NDF, and ADF were calculated using a nonlinear model (McDonald, 1981). The NLIN procedure of SAS (SAS Institute Inc., Cary, NC) was used to fit the following model:

$$
P=\mathrm{a}+\mathrm{b}\left(1-\mathrm{e}^{-\mathrm{c}(\mathrm{t}-\mathrm{L})}\right) \text { for } t>\mathrm{L},
$$

where $\mathrm{a}=$ soluble fraction $(\%), \mathrm{b}=$ slowly degradable $(\%), \mathrm{c}=$ fractional rate of disappearance of the $\mathrm{b}$ fraction $(/ \mathrm{h}), \mathrm{L}=$ lag time $(\mathrm{h})$, and $t=$ time of incubation (h).

Effective ruminal degradabilities (ERD) of DM, CP, $\mathrm{NDF}$, and $\mathrm{ADF}$ were calculated using the equation:

$$
\mathrm{ERD}=\mathrm{a}+[\mathrm{bc} /(\mathrm{c}+\mathrm{kp})] \times \mathrm{e}^{(-\mathrm{kpL})},
$$

where $\mathrm{kp}$ is the ruminal passage rate, calculated at $0.05 / \mathrm{h}$ for silage and $0.061 / \mathrm{h}$ for soybean meal and corn grain, from the equations developed by NRC (2001) for wet forages (silage) and concentrates.

\section{Ruminal Fermentation Characteristics and Protozoa Enumeration}

Ruminal fluid was collected from the anterior dorsal, anterior ventral, medium ventral, posterior dorsal, and posterior ventral locations within the rumen at $0,1,2$, 4,6 , and $8 \mathrm{~h}$ after the $0800 \mathrm{~h}$ feeding. Samples $(250 \mathrm{~mL} /$ site) were withdrawn using a syringe screwed to a stainless tube ending with a probe covered by a fine metal mesh (RT Rumen Fluid Collection Tube, Bar Diamond Inc.). Ruminal fluid $\mathrm{pH}$ was measured immediately after sampling (Accumet pH meter; Fisher Scientific, Montreal, Québec, Canada), and samples were acidified to $\mathrm{pH} 2$ with $50 \% \mathrm{H}_{2} \mathrm{SO}_{4}$ and frozen at $-20^{\circ} \mathrm{C}$ for later determination of VFA and $\mathrm{NH}_{3}-\mathrm{N}$ concentrations.

Protozoa counts were carried out on rumen fluid samples collected $2 \mathrm{~h}$ after the a.m. feeding. Ruminal fluid was strained through 2 layers of cheesecloth and a 3-mL portion of the rumen fluid strained was preserved using $3 \mathrm{~mL}$ of methyl green formalin-saline solution for protozoa enumeration (Ogimoto and Imai, 1981). Protozoa samples were stored at room temperature in darkness until counting. Protozoa were enumerated microscopically in a Levy-Hausser counting chamber (Hausser Scientific, Horsham, PA). Each sample was counted twice, and if the average of the duplicates differed by more than 10\%, the counts were repeated.

\section{Milk Production and Milk Composition}

Cows were milked twice daily in their stalls (0500 and $1700 \mathrm{~h}$ ) and milk yield was recorded at each milking. During the last week of each 28-d period, milk samples were taken from each cow at each milking and stored at $4^{\circ} \mathrm{C}$ with a preservative (2-bromo-2-nitropropan- 1,3 diol) until analyzed for fat, protein, urea $\mathrm{N}$, lactose, and somatic cell counts.

\section{Chemical Analyses}

Analytical DM was determined by oven drying at $105^{\circ} \mathrm{C}$ for $48 \mathrm{~h}$ (AOAC, 1990; method 930.15). Ash content was determined by incineration at $550^{\circ} \mathrm{C}$ overnight, and the OM content was calculated as the difference between 100 and the percentage of ash (AOAC 1990; method 942.05). Total N content was determined by thermal conductivity (Leco model FP-428 Nitrogen Determinator, Leco, St. Joseph, MI). The concentration of NDF was determined as described by Van Soest et al. 
(1991) without the use of sodium sulfite and with the inclusion of heat stable $\alpha$-amylase. The ADF content was determined according to AOAC (1990; method 973.18). The NDF and ADF procedures were adapted for use in an Ankom ${ }^{200}$ Fiber Analyzer (Ankom Technology Corp., Fairport, NY). Concentrations of $\mathrm{NH}_{3}-\mathrm{N}$ and VFA were analyzed by colorimetry using the phenyl-hypochlorite reaction (Weatherburn, 1967) and by GLC (Varian 3700; Varian Specialties Ltd., Brockeville, Ontario, Canada), respectively. Protein, fat, lactose, urea $\mathrm{N}$, and somatic cell counts in milk samples were analyzed by infrared spectrophotometer (System 4000 Milkoscan; Foss Electric, Hillerød, Denmark).

\section{Statistical Analyses}

Data were analyzed as a $4 \times 4$ Latin square design using the MIXED procedure (SAS Inst. Inc., Cary, NC). The model included treatment and period as fixed effects and cow as a random effect. The residual effect was initially included in the model, but it was removed because it was not significant. For the statistical analysis of ruminal fermentation characteristics ( $\left.\mathrm{pH}, \mathrm{VFA}, \mathrm{NH}_{3}-\mathrm{N}\right)$, sampling time, and sampling time $\times$ treatment were added to the model and analyzed as repeated measures using the MIXED procedure of SAS. Because there were no interactions between treatment and sampling time for any of the ruminal fermentation parameters measured, only averages over time are presented. Differences between treatments were declared significant at $P \leq 0.05$ using the Tukey correction for multiple comparisons, and trends were discussed at $P$ $\leq 0.10$ unless otherwise stated.

\section{RESULTS AND DISCUSSION}

\section{Intake of DM and Apparent Total-Tract Digestibility}

In this study, CIN, QCT, and YSE were supplemented at 1, 150, and $60 \mathrm{~g} / \mathrm{cow} / \mathrm{d}$, respectively. When expressed per kilogram of DMI, these amounts were equivalent to $43 \mathrm{mg} / \mathrm{kg}$ of DMI for CIN, $0.64 \%$ of dietary DM for QCT (providing $0.45 \%$ of condensed tannins), and $2,750 \mathrm{mg} / \mathrm{kg}$ of DMI for YSE (providing $275 \mathrm{mg}$ of saponins/kg of dietary DM).

Rates of application of plant extracts in ruminant nutrition varied widely among studies. For essential oils and their components, the dosage rates varied from 12 to $250 \mathrm{mg} / \mathrm{kg}$ of DMI depending on the type of the essential oil and the compound used. The dietary concentration of CIN employed in the present study is within the range of the concentrations of CIN reported by Cardozo et al. (2006) who showed that the combination of this compound (24 to $77 \mathrm{mg} / \mathrm{kg}$ of DMI) with eugenol
(12 to $38 \mathrm{mg} / \mathrm{kg}$ of DMI) favorably modified ruminal fermentation characteristics (i.e., reduction in $\mathrm{NH}_{3}-\mathrm{N}$ concentration and acetate proportion and an increase in small peptides + AA concentration and propionate proportion) in beef heifers fed a high-concentrate diet.

Carulla et al. (2005) observed that supplementing sheep diet with $2.5 \%$ of condensed tannins (DM basis) from Acacia mearnsii extract (black wattle tree) decreased digestibilities of $\mathrm{OM}, \mathrm{CP}, \mathrm{NDF}$, and $\mathrm{ADF}$. More recently, Beauchemin et al. (2007) reported that feeding 1 or $2 \%$ of the dietary DM as QCT (providing 0.9 or $1.8 \%$ of condensed tannins) depressed apparent total-tract digestibility of CP and ADIN in beef cattle, indicating that postruminal availability of AA may have been reduced. In our study, QCT was supplemented at a decreased quantity of tannins (i.e., $0.45 \%$ of dietary DM) with the objective to alleviate the negative effects of condensed tannins on diet digestibility.

Yucca schidigera saponins have been used at different dosage rates in ruminant diets, ranging from 40 to 5800 $\mathrm{mg} / \mathrm{kg}$ of DM (Calsamiglia et al., 2006). The dietary concentration of YSE used in this study (i.e., $2,750 \mathrm{mg} /$ $\mathrm{kg}$ of DMI providing $275 \mathrm{mg}$ of saponins/ $\mathrm{kg}$ of DMI) was selected on the basis of our previous results (Hristov et al., 1999), which showed that when supplied at a similar level (i.e., $260 \mathrm{mg} / \mathrm{kg}$ of DMI), saponins from Yucca schidigera enhanced ruminal fermentation (i.e., less $\mathrm{NH}_{3}-\mathrm{N}$ concentration and protozoa numbers and greater propionate proportion) in heifers.

Results of the effects of CIN, QCT, and YSE on DMI and total-tract digestibility are presented in Table 2 . Intake of DM was not affected by the addition of CIN in the diet. Benchaar et al. (2006b, 2007b) observed no change in DMI of lactating dairy cows fed $2 \mathrm{~g} / \mathrm{d}$ (i.e., 87 $\mathrm{mg} / \mathrm{kg}$ of DMI) or $750 \mathrm{mg} /$ d (i.e., $43 \mathrm{mg} / \mathrm{kg}$ of DMI) of a mixture of essential oil compounds (MEO) consisting of thymol, eugenol, vanillin, and limonene. However, feeding MEO at 2, 3, or $4 \mathrm{~g} / \mathrm{d}$ (i.e., 317, 476, and 630 $\mathrm{mg} / \mathrm{kg}$ of DMI, respectively) increased DMI in beef cattle fed a silage-based diet (Benchaar et al., 2006a). Cardozo et al. (2006) observed in a first trial that DMI decreased in beef heifers fed a high-concentrate diet (90\% concentrate $+10 \%$ barley straw) supplemented with a mixture consisting of $180 \mathrm{mg} / \mathrm{d}$ of CIN (i.e., 24 $\mathrm{mg} / \mathrm{kg}$ of DMI) and $90 \mathrm{mg} / \mathrm{d}$ of eugenol (i.e., $12 \mathrm{mg} / \mathrm{kg}$ of DMI). However, there was no effect in a second trial when the same mixture contained greater amounts of CIN (600 mg/d; $77 \mathrm{mg} / \mathrm{kg}$ of DMI) and eugenol (300 $\mathrm{mg} / \mathrm{d} ; 38 \mathrm{mg} / \mathrm{kg}$ of DMI). Reasons for discrepancy in DMI response to CIN and eugenol supplementation were not indicated in the study of Cardozo et al. (2006). In the same study by that group, DMI was increased by feeding anise $(2 \mathrm{~g} / \mathrm{d} ; 250 \mathrm{mg} / \mathrm{kg}$ of DMI) or capsicum (1 $\mathrm{g} / \mathrm{d} ; 120 \mathrm{mg} / \mathrm{kg}$ of DMI) extracts to beef cattle. Yang 
Table 2. Dry matter intake and apparent total-tract digestibility in lactating dairy cows fed a TMR without supplementation (control), or supplemented with cinnamaldehyde (CIN), quebracho condensed tannin extract (QCT), or Yucca schidigera saponin extract (YSE)

\begin{tabular}{|c|c|c|c|c|c|c|}
\hline \multirow[b]{2}{*}{ Item } & \multicolumn{4}{|c|}{ Treatment $^{1}$} & \multirow[b]{2}{*}{ SEM } & \multirow{2}{*}{$\begin{array}{c}\text { Treatmen } \\
P \text {-value }\end{array}$} \\
\hline & Control & CIN & QCT & YSE & & \\
\hline $\begin{array}{l}\text { DMI, } \mathrm{kg} / \mathrm{d} \\
\text { Digestibility, \% }\end{array}$ & $23.2^{\mathrm{ab}}$ & $23.1^{\mathrm{ab}}$ & $23.5^{\mathrm{b}}$ & $21.8^{\mathrm{a}}$ & 0.3 & 0.02 \\
\hline $\mathrm{DM}$ & 63.9 & 64.0 & 62.5 & 64.3 & 0.8 & 0.49 \\
\hline $\mathrm{OM}$ & 66.0 & 66.2 & 64.8 & 66.6 & 0.8 & 0.45 \\
\hline $\mathrm{CP}$ & 61.0 & 61.3 & 58.2 & 61.2 & 0.9 & 0.14 \\
\hline NDF & 54.3 & 55.7 & 53.1 & 55.9 & 1.2 & 0.41 \\
\hline $\mathrm{ADF}$ & 48.7 & 47.3 & 45.3 & 49.9 & 1.1 & 0.09 \\
\hline
\end{tabular}

${ }^{\mathrm{a}, \mathrm{b}}$ Means within rows with different superscripts differ $(P<0.05)$.

${ }^{1}$ Cinnamaldehyde was fed at $1 \mathrm{~g} / \mathrm{d}$ (43 mg/kg of DMI), QCT at $150 \mathrm{~g} / \mathrm{d}(0.64 \%$ of DMI), and YSE at $60 \mathrm{~g} / \mathrm{d}$ $(2,750 \mathrm{mg} / \mathrm{kg}$ of DMI).

et al. (2007) reported that feeding garlic at $5 \mathrm{~g} / \mathrm{d}$ (i.e., $245 \mathrm{mg} / \mathrm{kg}$ of DMI) and juniper berry at $2 \mathrm{~g} / \mathrm{d}$ (i.e., 98 $\mathrm{mg} / \mathrm{kg}$ of DMI) to lactating dairy cows had no effect on DMI. More recently, Chaves et al. (2008) observed no change in DMI of lambs fed CIN at $200 \mathrm{mg} / \mathrm{kg}$ of DMI in barley- or corn-based diet. Collectively, these results suggest that the effects of essential oils and their components on feed intake by ruminants vary depending on the type and the dose of the essential oils and the basal diet fed to animals.

The addition of QCT extract in the diet did not alter DMI. The effects of condensed tannins on feed intake in ruminants have been inconsistent among studies. Recently, Baah et al. (2007) observed no change in DMI in heifers supplemented with $0.6 \%$ of QCT extract (containing $70 \%$ of tannins) in a high-concentrate-based diet. Beauchemin et al. (2007) also reported that DMI was unaffected in beef cattle fed greater dietary amounts of QCT extract (1 and 2\% of DMI, containing $90 \%$ of tannins) in a high-forage-based diet. In contrast, other studies reported that DMI increased in sheep (Carulla et al., 2005) fed Acacia mearnsii extract (4.1\% of DMI, containing $61.5 \%$ of tannins) and in dairy cows (Woodward et al., 2001) fed ensiled condensed tannin-containing birdsfoot trefoil (Lotus corniculatus, containing $2.6 \%$ of tannins). Barry and McNabb (1999) reported that feed intake was not depressed in sheep fed Lotus pedunculatus containing 3 to $4 \%$ tannins. However, high concentrations of condensed tannins (7.5 to 10\%) in Lotus corniculatus substantially depressed feed intake in sheep. These results suggest that condensed tannins have negative effects on feed intake in ruminants when fed at high concentrations and the effects may vary with the source of condensed tannins employed.

Cows fed YSE had less $(P=0.05)$ DMI than cows fed the control diet (21.8 vs. $23.2 \mathrm{~kg} / \mathrm{d}$; Table 2$)$. Previous studies have showed that feeding YSE did not affect DMI in dairy cows (Wu et al., 1994: $68 \mathrm{mg} / \mathrm{kg}$ of DMI;
Wilson et al., 1998: $385 \mathrm{mg} / \mathrm{d}$ of DMI) and steers (Hussain and Cheeke, 1995: $75 \mathrm{mg} / \mathrm{kg}$ of DMI; Hristov et al., 1999: 1,960 and $5,825 \mathrm{mg} / \mathrm{kg}$ of DMI).

Apparent total-tract digestibilities of nutrients were not affected by CIN supplementation. Similarly, apparent total-tract digestibilities of $\mathrm{DM}, \mathrm{OM}$, and $\mathrm{CP}$ were unaffected in lactating cows fed MEO (Benchaar et al., 2006b, 2007b). Benchaar et al. (2007b) observed no changes in apparent total-tract digestibilities of fiber and starch in cows fed MEO at $43 \mathrm{mg} / \mathrm{kg}$ of DMI. However, digestibilities of these nutrients were increased when cows were fed a greater dose $(87 \mathrm{mg} / \mathrm{kg}$ of DMI) of MEO (Benchaar et al., 2006b), suggesting that the effects of essential oils and their compounds on fiber and starch digestion may be dose-dependent.

There were no significant effects of QCT supplementation on apparent total-tract digestibility of nutrients. Condensed tannins are a diverse group of polymeric flavanoids that readily complex with carbohydrates and proteins (Hagerman, 1992). The tannin-protein reaction has been widely exploited to improve efficiency of $\mathrm{N}$ utilization in ruminants (Aerts et al., 1999). However, the effects of condensed tannins on $\mathrm{N}$ metabolism in ruminants have been variable. Similarly to our findings, nutrient digestibility and duodenal $\mathrm{N}$ flows were not altered in heifers fed QCT in a high-concentrate-based diet (Baah et al., 2007). In contrast, Beauchemin et al. (2007) observed that apparent total-tract digestibility of CP decreased linearly with the addition of 1 or $2 \%$ of QCT (i.e., 0.9 and $1.8 \%$ of tannins), an indication that the availability of AA at the intestinal level may have been decreased in that study. Carulla et al. (2005) also reported that feeding Acacia mearnsii extract at $4.1 \%$ of DMI (providing 2.5\% of tannins on a DM basis) to sheep decreased apparent total-tract digestibility of CP. These results indicate that the effects of condensed tannins on protein metabolism vary with the concentration of tannins but also with the source of the plant used. 
Table 3. In situ degradation kinetics and effective degradability of soybean meal incubated in the rumen of lactating dairy cows fed a TMR without supplementation (control), or supplemented with cinnamaldehyde (CIN), quebracho condensed tannin extract (QCT), or Yucca schidigera saponin extract (YSE) ${ }^{1}$

\begin{tabular}{lcccccc}
\hline & \multicolumn{5}{c}{ Treatment $^{2}$} & \\
\cline { 2 - 4 } Item & Control & CIN & QCT & YSE & SEM & $\begin{array}{c}\text { Treatment } \\
P \text {-value }\end{array}$ \\
\hline Dry matter & & & & & & \\
a, \% & 35.1 & 33.8 & 34.8 & 33.9 & 0.6 & 0.42 \\
b, \% & 64.2 & 65.9 & 64.9 & 65.7 & 0.7 & 0.44 \\
c, /h & 0.095 & 0.076 & 0.078 & 0.081 & 0.006 & 0.24 \\
L, h & 1.52 & 1.04 & 2.35 & 2.82 & 0.67 & 0.32 \\
ERD, \% & 70.0 & 68.6 & 67.2 & 69.0 & 1.0 & 0.31 \\
Crude protein & & & & & & 0.24 \\
a, \% & 10.1 & 12.8 & 15.6 & 12.3 & 1.6 & 0.27 \\
b, \% & 89.8 & 87.2 & 84.4 & 87.7 & 1.7 & 0.78 \\
c, /h & 0.081 & 0.073 & 0.087 & 0.088 & 0.012 & 0.10 \\
L, h & 3.37 & 2.31 & 4.42 & 3.86 & 0.50 & 0.17 \\
ERD, \% & 57.6 & 54.2 & 52.9 & 55.2 & 1.3 & \\
\hline
\end{tabular}

${ }^{1} \mathrm{a}=$ soluble fraction; $\mathrm{b}=$ slowly degradable fraction; $\mathrm{c}=$ fractional rate of disappearance of the $\mathrm{b}$ fraction; $\mathrm{L}$ $=$ lag time; and $\mathrm{ERD}=$ effective ruminal degradability.

${ }^{2}$ Cinnamaldehyde was fed at $1 \mathrm{~g} / \mathrm{d}(43 \mathrm{mg} / \mathrm{kg}$ of DMI), QCT at $150 \mathrm{~g} / \mathrm{d}(0.64 \%$ of DMI), and YSE at $60 \mathrm{~g} / \mathrm{d}$ $(2,750 \mathrm{mg} / \mathrm{kg}$ of DMI).

In fact, a diet containing $1.8 \%$ of condensed tannins through Lotus pedunculatus resulted in a significant decrease of ruminal $\mathrm{NH}_{3}-\mathrm{N}$ and VFA concentrations and reduced $\mathrm{CP}$ digestibility, whereas the same amount of condensed tannins from Lotus corniculatus had lesser effects (Waghorn and Shelton, 1997).

Apparent total-tract digestibilities of nutrients were not changed by YSE supplementation. The effects of YSE on diet digestibility have varied among studies probably related to dosing levels and the type of diets fed. For instance, Valdez et al. (1986) reported that apparent total-tract digestibility of DM was not affected in lactating cows fed YSE at $77 \mathrm{mg} / \mathrm{kg}$ of dietary DM. Similarly, Hristov et al. (1999) observed no changes in apparent total-tract digestibilities of DM, CP, and NDF in beef heifers fed $60 \mathrm{~g} / \mathrm{d}$ of YSE (containing $4.4 \%$ of saponins). However, Goetsch and Owens (1985) found that feeding the YSE at $44 \mathrm{mg} / \mathrm{kg}$ of DMI to lactating dairy cows increased apparent total-tract digestibility of OM, but no changes were observed in total-tract digestibilities of starch, ADF, and N.

\section{In Situ Ruminal Degradation Kinetics}

In situ ruminal degradation kinetics and effective ruminal degradabilities of soybean meal (Table 3), grass silage (Table 4), or corn grain (Table 5) were not changed by the addition of CIN, QCT, or YSE in the diet, although supplementation with QCT numerically decreased ERD of soybean meal DM (67.2 vs. $70.0 \%)$ and tended $(P=0.13)$ to reduce ERD of soybean meal CP (52.9 vs. $57.6 \%)$. The effect of tannins on ruminal protein degradation is well known. For instance, in situ and in vitro experiments have shown that condensed tannins in Lotus pedunculatus and Lotus corniculatus decreased the rates of both solubilization and degradation of forage proteins by rumen microorganisms (Barry and McNabb, 1999). Little work, however, has been reported on the effects of concentrated sources of condensed tannins such as quebracho extract on in situ ruminal degradation of protein.

The reported effects of essential oils on in situ ruminal protein degradation were variable among studies. Benchaar et al. (2006b) observed no effects of feeding MEO to lactating cows on in situ ruminal degradabilities of CP (i.e., soybean meal), fiber (grass silage), and starch (i.e., corn), which was consistent with the lack of effects of MEO on the counts of total cellulolytic and amylolytic bacteria counts observed in that study. Molero et al. (2004) used growing heifers to evaluate the influence of MEO (700 mg/head per day) on in situ ruminal degradability of proteins in soybean meal, corn gluten feed, fish meal, green peas, sunflower meal, and lupin seeds. Of the 5 protein supplements examined, MEO only tended to reduce the effective ruminal protein degradabilities of lupin seeds, green peas, and soybean meal, and the reductions were too small to have any likely nutritional impact on ruminal protein metabolism in the animal. Based on the results of Molero et al. (2004), Hart et al. (2007) speculated that the effect of essential oils (i.e., MEO) on ruminal degradation of protein seems to be selective with the effects being more pronounced with the rapidly degradable protein sources than with the more resistant substrates.

The effects of YSE on ruminal digestion have varied with diets and dosing levels. In agreement with our 
Table 4. In situ degradation kinetics and effective degradability of grass silage incubated in the rumen of lactating dairy cows fed a TMR without supplementation (control), or supplemented with cinnamaldehyde (CIN), quebracho condensed tannin extract (QCT), or Yucca schidigera saponin extract (YSE) ${ }^{1}$

\begin{tabular}{|c|c|c|c|c|c|c|}
\hline \multirow[b]{2}{*}{ Item } & \multicolumn{4}{|c|}{ Treatment $^{2}$} & \multirow[b]{2}{*}{ SEM } & \multirow{2}{*}{$\begin{array}{c}\text { Treatment } \\
P \text {-value }\end{array}$} \\
\hline & Control & CIN & $\mathrm{QCT}$ & YSE & & \\
\hline \multicolumn{7}{|c|}{ Dry matter } \\
\hline $\mathrm{a}, \%$ & 31.5 & 32.2 & 31.8 & 32.5 & 0.2 & 0.06 \\
\hline $\mathrm{b}, \%$ & 54.3 & 51.3 & 51.2 & 50.9 & 1.2 & 0.26 \\
\hline $\mathrm{c}, / \mathrm{h}$ & 0.032 & 0.035 & 0.035 & 0.033 & 0.002 & 0.70 \\
\hline $\mathrm{L}, \mathrm{h}$ & 2.21 & 3.27 & 3.44 & 2.73 & 0.79 & 0.65 \\
\hline ERD, \% & 50.8 & 49.8 & 49.8 & 50.3 & 0.9 & 0.84 \\
\hline \multicolumn{7}{|l|}{$\mathrm{NDF}$} \\
\hline $\mathrm{a}, \%$ & 6.64 & 6.88 & 6.80 & 6.38 & 0.23 & 0.47 \\
\hline $\mathrm{b}, \%$ & 76.5 & 72.1 & 73.0 & 74.7 & 1.7 & 0.36 \\
\hline $\mathrm{c}, / \mathrm{h}$ & 0.028 & 0.031 & 0.029 & 0.027 & 0.002 & 0.40 \\
\hline $\mathrm{L}, \mathrm{h}$ & 3.41 & 4.43 & 3.96 & 2.69 & 1.07 & 0.70 \\
\hline ERD, \% & 29.5 & 28.5 & 28.6 & 29.3 & 1.5 & 0.99 \\
\hline \multicolumn{7}{|l|}{$\mathrm{ADF}$} \\
\hline $\mathrm{a}, \%$ & 1.49 & 2.79 & 2.53 & 1.37 & 0.47 & 0.17 \\
\hline $\mathrm{b}, \%$ & 83.6 & 76.1 & 75.3 & 79.0 & 3.2 & 0.28 \\
\hline $\mathrm{c}, / \mathrm{h}$ & 0.027 & 0.031 & 0.032 & 0.027 & 0.002 & 0.41 \\
\hline $\mathrm{L}, \mathrm{h}$ & 2.03 & 2.59 & 3.39 & 0.83 & 0.80 & 0.25 \\
\hline ERD, \% & 27.5 & 27.6 & 27.3 & 27.7 & 1.3 & 0.99 \\
\hline
\end{tabular}

${ }^{1} \mathrm{a}=$ soluble fraction; $\mathrm{b}=$ slowly degradable fraction; $\mathrm{c}=$ fractional rate of disappearance of the $\mathrm{b}$ fraction; $\mathrm{L}$

$=$ lag time; and $\mathrm{ERD}=$ effective ruminal degradability.

${ }^{2}$ Cinnamaldehyde was fed at $1 \mathrm{~g} / \mathrm{d}(43 \mathrm{mg} / \mathrm{kg}$ of DMI), QCT at $150 \mathrm{~g} / \mathrm{d}(0.64 \%$ of DMI), and YSE at $60 \mathrm{~g} / \mathrm{d}$ $(2,750 \mathrm{mg} / \mathrm{kg}$ of DMI).

findings, Goetsch and Owens (1985) found no effects of feeding YSE (44 mg/kg of DMI) to growing cattle on in situ rates of ruminal disappearance of soybean meal, corn, and alfalfa hay, whereas Valdez et al. (1986) observed decreased in situ rates of disappearance of OM, $\mathrm{ADF}$, and $\mathrm{CP}$ of a TMR substrate incubated in the rumen of lactating cows fed YSE at $77 \mathrm{mg} / \mathrm{kg}$ of DMI.

\section{Ruminal Fermentation Characteristics}

Ruminal $\mathrm{pH}$, concentrations of $\mathrm{NH}_{3}-\mathrm{N}$ and total VFA, and molar proportions of individual VFA were not affected by the addition of CIN in the diet (Table
6), which is consistent with the lack of effect of CIN on ruminal feed digestion. The effects of CIN on ruminal fermentation characteristics have been variable among studies. Using a continuous culture fermenter maintained at constant $\mathrm{pH}(6.4 \pm 0.05)$, Cardozo et al. (2004) observed no effects of CIN addition (0.22 $\mathrm{mg} / \mathrm{L}$ of ruminal fluid) on total VFA concentration and molar proportions of individual VFA. Based on these findings, the authors concluded that the dose of $0.22 \mathrm{mg} / \mathrm{L}$ of CIN may have been too low to affect rumen microbial fermentation. In a subsequent study by the same authors, the addition of CIN at $2.2 \mathrm{mg} / \mathrm{L}$ in continuous culture fermenters maintained at a constant

Table 5. In situ degradation kinetics and effective degradability of corn grain incubated in the rumen of lactating dairy cows fed a TMR without supplementation (control), or supplemented with cinnamaldehyde (CIN), quebracho condensed tannin extract (QCT), or Yucca schidigera saponin extract (YSE) ${ }^{1}$

\begin{tabular}{|c|c|c|c|c|c|c|}
\hline \multirow[b]{2}{*}{ Item } & \multicolumn{4}{|c|}{ Treatment $^{2}$} & \multirow[b]{2}{*}{ SEM } & \multirow{2}{*}{$\begin{array}{c}\text { Treatment } \\
P \text {-value }\end{array}$} \\
\hline & Control & CIN & $\mathrm{QCT}$ & YSE & & \\
\hline \multicolumn{7}{|l|}{ Dry matter } \\
\hline a, $\%$ & 27.0 & 27.6 & 27.9 & 27.6 & 1.0 & 0.93 \\
\hline b, $\%$ & 72.0 & 72.3 & 71.4 & 72.0 & 1.2 & 0.97 \\
\hline $\mathrm{c}, / \mathrm{h}$ & 0.055 & 0.050 & 0.053 & 0.050 & 0.004 & 0.79 \\
\hline $\mathrm{L}, \mathrm{h}$ & 1.53 & 0.94 & 2.41 & 1.70 & 0.53 & 0.24 \\
\hline ERD, \% & 60.6 & 58.7 & 57.8 & 60.2 & 0.7 & 0.10 \\
\hline
\end{tabular}

${ }^{1} \mathrm{a}=$ soluble fraction; $\mathrm{b}=$ slowly degradable fraction; $\mathrm{c}=$ fractional rate of disappearance of the $\mathrm{b}$ fraction; $\mathrm{L}$

$=$ lag time; and ERD = effective ruminal degradability.

${ }^{2}$ Cinnamaldehyde was fed at $1 \mathrm{~g} / \mathrm{d}(43 \mathrm{mg} / \mathrm{kg}$ of DMI), QCT at $150 \mathrm{~g} / \mathrm{d}(0.64 \%$ of DMI), and YSE at $60 \mathrm{~g} / \mathrm{d}$ $(2,750 \mathrm{mg} / \mathrm{kg}$ of DMI). 
Table 6. Ruminal fermentation characteristics in lactating dairy cows fed a TMR without supplementation (control), or supplemented with cinnamaldehyde (CIN), quebracho condensed tannin extract (QCT), or Yucca schidigera saponin extract (YSE)

\begin{tabular}{|c|c|c|c|c|c|c|}
\hline \multirow[b]{2}{*}{ Item } & \multicolumn{4}{|c|}{ Treatment $^{1}$} & \multirow[b]{2}{*}{ SEM } & \multirow{2}{*}{$\begin{array}{c}\text { Treatment } \\
P \text {-value }\end{array}$} \\
\hline & Control & CIN & QCT & YSE & & \\
\hline $\mathrm{pH}$ & 6.68 & 6.73 & 6.66 & 6.61 & 0.05 & 0.40 \\
\hline $\mathrm{NH}_{3}-\mathrm{N}, \mathrm{mg} / \mathrm{L}$ & 159.5 & 148.6 & 132.2 & 146.3 & 6.64 & 0.13 \\
\hline Total VFA, $\mathrm{m} M$ & 133.04 & 133.7 & 136.5 & 134.9 & 2.8 & 0.83 \\
\hline \multicolumn{7}{|l|}{ VFA, mol/100 mol } \\
\hline Acetate $(\mathrm{A})$ & 65.0 & 65.2 & 64.7 & 65.1 & 0.1 & 0.10 \\
\hline Propionate $(\mathrm{P})$ & 19.5 & 19.2 & 19.8 & 19.8 & 0.2 & 0.08 \\
\hline Butyrate & 11.1 & 11.3 & 11.3 & 11.1 & 0.1 & 0.33 \\
\hline Isobutyrate & 0.98 & 0.96 & 0.93 & 0.91 & 0.03 & 0.40 \\
\hline Valerate & $1.32^{\mathrm{b}}$ & $1.28^{\mathrm{ab}}$ & $1.29^{\mathrm{ab}}$ & $1.23^{\mathrm{a}}$ & 0.02 & 0.04 \\
\hline Isovalerate & 1.69 & 1.60 & 1.58 & 1.47 & 0.06 & 0.15 \\
\hline Caproate & 0.43 & 0.42 & 0.42 & 0.39 & 0.01 & 0.34 \\
\hline $\mathrm{A}: \mathrm{P}^{\mathrm{T}}$ & 3.35 & 3.41 & 3.28 & 3.29 & 0.03 & 0.08 \\
\hline
\end{tabular}

$\mathrm{pH}$ did not affect total VFA concentration and propionate proportion but decreased acetate proportion and increased butyrate proportion (Busquet et al., 2005a). When greater doses of CIN (31.2 and $312 \mathrm{mg} / \mathrm{L}$ ) were used under similar experimental conditions, Busquet et al. (2005b) observed no change in total VFA concentration, a decrease in acetate proportion, an increase in propionate proportion at the lesser dose (i.e., 31.2 $\mathrm{mg} / \mathrm{L}$ ), and an increase in the proportion of butyrate at the greater dosage rate (i.e., $312 \mathrm{mg} / \mathrm{L}$ ). These results suggest that the effect of CIN on VFA is dose-dependent and is more pronounced when used at high than at low or moderate dosage rates. However, high dosage rates of CIN (>300 mg/L) may result in a decrease in total VFA concentration as shown by Busquet et al. (2006). Such change is not nutritionally beneficial as VFA represent the main source of metabolizable energy to ruminants. Some of the discrepancies between studies in CIN effects on VFA concentration and pattern may be related to ruminal pH. Indeed, Cardozo et al. (2005) observed in batch culture incubations $(24 \mathrm{~h})$ that at $\mathrm{pH}$ 7.0, CIN decreased the concentration of total VFA and increased the acetate:propionate ratio, which is not nutritionally beneficial to ruminants because efficiency of energy utilization may be compromised if similar changes were expressed in vivo. In contrast, at $\mathrm{pH}$ 5.5, CIN decreased the acetate:propionate ratio. Such a fermentation profile is more efficient and would benefit ruminants fed high-concentrate-based diets in beef or sheep production systems.

In the present study, supplementation with CIN did not alter $\mathrm{N}$ metabolism. The effects of CIN on ruminal $\mathrm{N}$ metabolism have been inconsistent among studies. Cardozo et al. (2004) reported that the addition (0.22 $\mathrm{mg} / \mathrm{L}$ of ruminal fluid) of cinnamon oil (containing $59 \%$ of CIN) in a continuous culture fermenter maintained at constant $\mathrm{pH}$ did not affect $\mathrm{NH}_{3}-\mathrm{N}$ concentration but increased the concentration of peptide- $\mathrm{N}$ and numerically decreased AA-N concentration, suggesting that peptidolysis was inhibited. Surprisingly, no changes were observed in $\mathrm{N}$ metabolism (i.e., concentrations of $\mathrm{NH}_{3}-\mathrm{N}$, large peptide- $\mathrm{N}$, and small peptide- $\mathrm{N}+\mathrm{AA}$ ) when CIN was supplied at greater concentrations $(2.2$, 31.2 , and $312 \mathrm{mg} / \mathrm{L}$ ) in continuous culture fermenters (Busquet et al., 2005a,b). More recently, Chaves et al. (2008) observed no changes in ruminal $\mathrm{NH}_{3}-\mathrm{N}$ concentration in lambs supplemented with CIN $(200 \mathrm{mg} / \mathrm{kg}$ of DMI) in barley- or corn-based diet.

The lack of effects of CIN on rumen microbial fermentation observed in this study may be attributed to a possible adaptation of rumen microbes. Microbial populations exhibit a remarkable capacity to adapt to a wide variety of antimicrobial agents, and adaptation of the rumen microbial ecosystem to essential oils has been reported in previous studies. Cardozo et al. (2004) and Busquet et al. (2005a) observed that the effects of essential oils on rumen microbial fermentation disappeared after $6 \mathrm{~d}$ of incubation in a continuous culture system.

There were no effects of feeding QCT to dairy cows on ruminal $\mathrm{pH}$, total VFA concentration, and molar proportions of individual VFA (Table 6). The effects of condensed tannins on ruminal total VFA concentration and VFA pattern have been variable among studies depending on the dosage rate and the source of condensed tannins. For example, Beauchemin et al. (2007) reported that despite a lack of effect of QCT supplementation on total-tract digestibility of DM, 
increasing supplementation levels of QCT (up to $2 \%$ of DMI $)$ tended $(P=0.08)$ to decrease ruminal total VFA concentration, and decreased acetate molar proportion and the acetate:propionate ratio. In contrast, despite a reduction in total-tract digestibility of OM, Carulla et al. (2005) observed no change in total VFA concentration in sheep supplemented with Acacia mearnsii extract, but molar proportion of acetate decreased and that of propionate increased in sheep fed diets supplemented with condensed tannins.

Ruminal $\mathrm{NH}_{3}-\mathrm{N}$ concentration tended to decrease $(-17 \% ; P=0.09)$ in cows fed the QCT-supplemented diet compared with cows fed the control diet (Table 6 ). This reduction is within the range of the decreases recently reported by Beauchemin et al. (2007) for beef cattle ( -9 to $-12 \%)$ and Carulla et al. (2005) for sheep $(-9 \%)$ fed greater concentrations of condensed tannins (up to 1.8 and $2.5 \%$, respectively) than the concentration used in this study (i.e., $0.45 \%$ ). The lesser $\mathrm{NH}_{3} \mathrm{~N}$ concentration observed in our study is consistent with the numerical difference $(P=0.13)$ observed for ERD of CP of soybean meal between cows fed the QCT-supplemented diet as compared with cows fed the control diet (52.9 vs. $57.6 \%$; Table 3 ).

The limited effects of condensed tannins on digestion and ruminal fermentation observed in our study may be due to the relatively low concentration used (i.e., $0.45 \%$ ) compared with other in vivo studies (Carulla et al., 2005: 2.5\%; Beauchemin et al., 2007: 0.8 and 1.9\%). In the 2 later studies, however, the greater concentrations of condensed tannins resulted in a reduction of nutrient digestibility. Results from the present study as well as those from Carulla et al. (2005) and Beauchemin et al. (2007) illustrate the difficulty in selecting concentrations of condensed tannins to positively influence ruminal protein metabolism without conferring a negative response in overall diet digestibility.

Condensed tannins extracted from different plants vary greatly in their capacity to bind proteins and carbohydrates (McAllister et al., 2005). Thus, it is possible that quebracho condensed tannins are less effective in altering nutrient digestion, in particular $\mathrm{N}$ metabolism, than other sources of condensed tannins such as Acacia mearnsii (Carulla et al., 2005) or tannin-containing forages such as Lotus pedunculatus (Waghorn and Shelton, 1997). It is equally possible that rumen microbial populations were able to adapt to tannins as reported by Makkar (2003).

The addition of YSE had no effects on ruminal $\mathrm{pH}$, total VFA concentration, and the molar proportions of individual VFA, with the exception of valerate molar proportion, which was greater in cows fed the YSE-supplemented diet as compared with cows fed the control diet (Table 6). Other studies with dairy cows (Valdez et al., 1986; Wu et al., 1994) or steers (Hristov et al., 1999) also observed no effects of diet supplementation with YSE on ruminal total VFA concentration. Reported effects of saponins on VFA pattern have varied with diets, levels of application, and the concentration of active components in Yucca schidigera extract. For instance, Valdez et al. (1986) and Wu et al. (1994) reported no changes in VFA profile in dairy cows fed Yucca schidigera saponins, whereas Hristov et al. (1999) observed increased propionate molar proportion in steers supplemented with YSE. Cardozo et al. (2005) showed in vitro that $\mathrm{pH}$ of incubation media greatly influences the effect of Yucca schidigera saponins on VFA profile. At $\mathrm{pH} 5.5$, the addition of up to $30 \mathrm{mg} / \mathrm{L}$ of Yucca schidigera saponins reduced the molar proportion of acetate and increased that of propionate, whereas no effects were observed at $\mathrm{pH}$ 7.0.

The addition of YSE did not affect ruminal $\mathrm{NH}_{3}-\mathrm{N}$ concentration (Table 6), which is consistent with the lack of effects of YSE on in situ ruminal degradation of soybean meal (Table 3). The glycofractions of Yucca saponins are known to bind ammonia. Reported research on the effects of saponins on ruminal $\mathrm{NH}_{3}-\mathrm{N}$ concentration has been inconsistent. In vitro studies by Wallace et al. (1994) and Wang et al. (2000) showed that adding YSE at $10,000 \mathrm{mg} / \mathrm{L}$ of ruminal fluid caused a decrease in ruminal $\mathrm{NH}_{3}-\mathrm{N}$ concentration. However, in vivo studies with dairy cows (Wu et al., 1994; Wilson et al., 1998) and steers (Goetsch and Owens, 1985; Hussain and Cheeke, 1995) found no effects of YSE on ruminal $\mathrm{NH}_{3}-\mathrm{N}$ concentration.

\section{Protozoal Populations}

Supplementation with CIN had no effect on total numbers of protozoa as well as the numbers of Dasytricha, Diplodinium, Entodinium, and Polyplastron (Table 7). However, the number of Isotricha was greater $(P=$ $0.05)$ in ruminal fluid of cows fed CIN than in that of cows fed the control diet. Information on the effects of essential oils and their component on ruminal protozoa populations is scarce, and to our knowledge the effects of CIN on protozoa counts have not been assessed previously. Newbold et al. (2004) and Benchaar et al. (2006b, $2007 \mathrm{~b}$ ) observed no changes in ruminal protozoa counts in sheep and dairy cows supplemented with 110 or 750 $\mathrm{mg} / \mathrm{d}$ of MEO, respectively. More recently, Cardozo et al. (2006) reported no change in entodiniomorphs and an increase in holotrichs numbers in beef heifers supplemented with a mixture of CIN (24 mg/kg of DMI) and eugenol $(12 \mathrm{mg} / \mathrm{kg}$ of DMI $)$ in a high-concentrate based diet. However, no effects were observed at greater dosage rate of the mixture $(77 \mathrm{mg} / \mathrm{kg}$ of DMI of CIN plus $38 \mathrm{mg} / \mathrm{kg}$ of DMI of eugenol). Benchaar et al. (2008) 
Table 7. Total numbers and distribution by genera of ruminal ciliate protozoa in lactating dairy cows fed a TMR without supplementation (control), or supplemented with cinnamaldehyde (CIN), quebracho condensed tannin extract (QCT), or Yucca schidigera saponin extract (YSE)

\begin{tabular}{|c|c|c|c|c|c|c|}
\hline \multirow[b]{2}{*}{ Item } & \multicolumn{4}{|c|}{ Treatment $^{1}$} & \multirow[b]{2}{*}{ SEM } & \multirow{2}{*}{$\begin{array}{c}\text { Treatmen } \\
P \text {-value }\end{array}$} \\
\hline & Control & CIN & $\mathrm{QCT}$ & YSE & & \\
\hline \multicolumn{7}{|l|}{ Protozoa, $\log _{10} / \mathrm{mL}$} \\
\hline Total & 5.84 & 5.94 & 5.81 & 5.79 & 0.05 & 0.30 \\
\hline Dasytricha spp. & 4.41 & 4.07 & 4.01 & 3.98 & 0.24 & 0.60 \\
\hline Diplodinium spp. & 3.12 & 2.82 & 2.67 & 3.87 & 0.52 & 0.43 \\
\hline Entodinium spp. & 5.34 & 5.89 & 5.78 & 5.75 & 0.70 & 0.42 \\
\hline Isotricha spp. & 4.23 & 4.46 & 4.10 & 4.22 & 0.07 & 0.09 \\
\hline Polyplastron spp. & 3.69 & 3.05 & 3.57 & 2.72 & 0.60 & 0.64 \\
\hline
\end{tabular}

reported that in general, essential oils and their components have no marked effects on numbers, activity, or both, of ruminal ciliate protozoa.

Supplementation with QCT had no effect on the numbers and the generic distribution of ruminal ciliate protozoa (Table 7). Information on the influence of condensed tannins on ruminal protozoal populations in vivo is scarce. In one study, feeding QCT extract to beef heifers did not alter the numbers of protozoa subpopulations in the rumen (Baah et al., 2007). Using a RUSITEC fermenter, Makkar et al. (1995) investigated the effects of increasing concentrations of condensed tannins from quebracho extract $(0.05,0.1$, and $0.2 \mathrm{mg}$ of tannins $/ \mathrm{mL}$ of ruminal fluid) on rumen microbial fermentation. Total protozoa counts were not changed by the addition of QCT at $0.05 \mathrm{mg} / \mathrm{mL}$ but decreased at the concentrations of 0.1 and $0.2 \mathrm{mg} / \mathrm{mL}$. Entodiniomorph numbers were only decreased at the greatest concentration of tannins, whereas holotrich numbers were reduced at all tannin concentrations. In a more recent study, Carulla et al. (2005) observed that feeding tannins from Acacia mearnsii extract to sheep had no effects on total counts of protozoa and entodiniomorphs but decreased the numbers of holotrich ciliate protozoa. Results from the studies of Makkar et al. (1995) and Carulla et al. (2005) suggest that holotrichs may be more sensitive to condensed tannins than entodiniomorphs. Although the effects of condensed tannins on ruminal protozoal populations have been inconsistent depending on the concentration and the origin of condensed tannins, Makkar (2003) suggested that there is some evidence for lesser protozoal numbers in the presence of tannins.

Saponins from different sources have been found to have antiprotozoal activity and have been suggested as possible defaunating agents (Wallace et al., 1994). In the present study, supplementation with YSE did not affect total numbers and distribution by genera of ruminal ciliate protozoa (Table 7). Reported effects of saponins on ruminal protozoa have been variable among studies, apparently related to dosing levels. Supplementation with Yucca schidigera saponins decreased protozoal numbers in vitro (Makkar et al., 1998: 600 to 1,200 mg/ $\mathrm{mL}$ of pure saponins; Pen et al., 2006a: 1.0 to $6.0 \mathrm{~mL} / \mathrm{L}$ of YSE) and in vivo (Valdez et al., 1986; Hristov et al., 1999). However, other in vitro (Hristov et al., 2003: 1,000 to 4,000 mg/L; Sliwinski et al., 2002: 1 to 100 $\mathrm{mg} / \mathrm{kg}$ of DM substrate) and in vivo (Pen et al., 2006b: 1,180 to $1,477 \mathrm{mg} / \mathrm{kg}$ of DMI; Baah et al., 2007: 8,000 $\mathrm{mg} / \mathrm{kg}$ of DMI) studies reported no effects of plant-containing saponins on ruminal protozoa numbers. Hristov et al. (2004) indicated that the effects of saponins on ruminal fermentation and protozoal populations were generally significant at high application rates. The lack of effects of saponins on rumen fermentation and protozoa counts observed in several in vivo studies may be also attributed to bacterial degradation (Newbold et al., 1997) and salivary inactivation (Teferedegne, 2000) of saponins.

\section{Milk Production and Milk Composition}

Results of the effects of diet supplementation with CIN, QCT, or YSE on milk production and milk composition are presented in Table 8.

Milk and 4\% FCM yields and milk composition were not changed by CIN, QCT, or YSE supplementation, which is consistent with the limited of these plant extracts on DMI, nutrients digestion, and ruminal fermentation characteristics. Benchaar et al. (2006b, $2007 \mathrm{~b})$ reported no changes in milk production and milk composition in dairy cows fed MEO. In a review, Makkar (2003) indicated that the greater animal performance observed in some studies when animals were fed condensed tannins has been related to the protection of dietary protein from rumen microbial degradation, resulting in increased supply of AA to the intestine and a greater absorption to blood. Other studies reported 
Table 8. Milk production and milk composition of dairy cows fed a TMR without supplementation (control), or supplemented with cinnamaldehyde (CIN), quebracho condensed tannin extract (QCT), or Yucca schidigera saponin extract (YSE)

\begin{tabular}{|c|c|c|c|c|c|c|}
\hline \multirow[b]{2}{*}{ Item } & \multicolumn{4}{|c|}{ Treatment $^{1}$} & \multirow[b]{2}{*}{ SEM } & \multirow{2}{*}{$\begin{array}{c}\text { Treatment } \\
P \text {-value }\end{array}$} \\
\hline & Control & CIN & QCT & YSE & & \\
\hline Milk production, $\mathrm{kg} / \mathrm{d}$ & 33.6 & 34.2 & 33.2 & 31.5 & 0.9 & 0.30 \\
\hline $4 \%$ FCM, kg/d & 34.5 & 35.2 & 33.6 & 33.2 & 1.1 & 0.63 \\
\hline \multicolumn{7}{|l|}{ Milk composition, $\%$} \\
\hline Fat & 4.33 & 4.28 & 4.21 & 4.42 & 0.09 & 0.43 \\
\hline Protein & 3.59 & 3.51 & 3.49 & 3.50 & 0.07 & 0.70 \\
\hline Lactose & 4.52 & 4.49 & 4.45 & 4.38 & 0.04 & 0.10 \\
\hline Milk urea N, mg/dL & 18.0 & 18.5 & 18.3 & 16.3 & 0.7 & 0.18 \\
\hline $\mathrm{SCC}, \log _{10}$ & 4.43 & 4.46 & 4.47 & 5.01 & 1.45 & 0.08 \\
\hline \multicolumn{7}{|l|}{ Milk yield, $\mathrm{kg} / \mathrm{d}$} \\
\hline Fat & 1.40 & 1.43 & 1.36 & 1.37 & 0.05 & 0.76 \\
\hline Protein & 1.18 & 1.17 & 1.13 & 1.07 & 0.03 & 0.14 \\
\hline Lactose & 1.54 & 1.56 & 1.51 & 1.40 & 0.05 & 0.26 \\
\hline
\end{tabular}

no changes in milk production and milk composition of dairy cows fed diets supplemented with YSE (Valdez et al., 1986; Wu et al., 1994; Wilson et al., 1998).

\section{CONCLUSIONS}

Cinnamaldehyde ( $1 \mathrm{~g} / \mathrm{cow}$ per day; $43 \mathrm{mg} / \mathrm{kg}$ of DMI), quebracho condensed tannin extract $(150 \mathrm{~g} / \mathrm{cow}$ per day; $0.64 \%$ of DMI, providing $0.45 \%$ of condensed tannins), and Yucca schidigera saponin extract (60 g/ cow per day; $2,750 \mathrm{mg} / \mathrm{kg}$ of DMI, providing $275 \mathrm{mg} /$ $\mathrm{kg}$ of saponins) exerted negligible effects on digestion, rumen microbial fermentation, protozoal numbers, milk production, and milk composition. Even though CIN has been reported to modulate rumen microbial fermentation in vitro at high dosage rates, results from this study suggest that it may be a challenge to achieve such effects in vivo. The lack of effects of these plant extracts observed under our experimental conditions may be due to the adaptation of ruminal microbes, to bacterial degradation of these compounds, or both.

\section{ACKNOWLEDGMENTS}

The authors thank L. Croteau (Agriculture and AgriFood Canada, Sherbrooke), C. Barkley (Agriculture and Agri-Food Canada, Lethbridge), and F. Vanherk (Agriculture and Agri-Food Canada, Lethbridge) for their technical assistance, S. Méthot (Agriculture and Agri-Food Canada, Sherbrooke) for his help with statistical analyses, and the barn staff of the Dairy and Swine Research Centre of Sherbrooke (Québec, Canada) for their care of the cows. Provision of quebracho extract by Unitan, Yucca schidigera extract by Desert King International, and CIN by Phodé is also gratefully acknowledged. This study was financially supported by Agriculture and Agri-Food Canada.

\section{REFERENCES}

Aerts, R. J., T. N. Barry, and W. C. McNabb. 1999. Polyphenols and agriculture: Beneficial effects of proanthocyanidins in forages. Agric. Ecosyst. Environ. 75:1-12.

Association of Official Analytical Chemists. 1990. Official Methods of Analysis. 15th ed. AOAC, Arlington, VA.

Baah, J., M. Ivan, A. N. Hristov, K. M. Koenig, L. M. Rode, and T. A. McAllister. 2007. Effects of potential dietary antiprotozoal supplements on rumen fermentation and digestibility in heifers. Anim. Feed Sci. Technol. 137:126-137.

Barry, T. N., and W. C. McNabb. 1999. The implications of condensed tannins on the nutritive value of temperate forages fed to ruminants. Br. J. Nutr. 81:263-272.

Beauchemin, K. A., S. M. McGinn, T. F. Martinez, and T. A. McAllister. 2007. Use of condensed tannin extract from quebracho trees to reduce methane emissions from cattle. J. Anim. Sci. 85:1990-1996.

Benchaar, C., S. Calsamiglia, A. V. Chaves, G. R. Fraser, D. Colombatto, T. A. McAllister, and K. A. Beauchemin. 2008. A review of plant-derived essential oils in ruminant nutrition and production. Anim. Feed Sci. Technol. 145:209-228.

Benchaar, C., A. V. Chaves, G. R. Fraser, Y. Wang, K. A. Beauchemin, and T. A. McAllister. 2007a. Effects of essential oils and their components on in vitro rumen microbial fermentation. Can. J. Anim. Sci. 87:413-419.

Benchaar, C., J. L. Duynisveld, and E. Charmley. 2006a. Effects of monensin and increasing dose levels of a mixture of essential oil compounds on intake, digestion and growth performance of beef cattle. Can. J. Anim. Sci. 86:91-96.

Benchaar, C., H. V. Petit, R. Berthiaume, D. R. Ouellet, J. Chiquette, and P. Y. Chouinard. 2007b. Effects of essential oils on digestion, ruminal fermentation, rumen microbial populations, milk production, and milk composition in dairy cows fed alfalfa silage or corn silage. J. Dairy Sci. 90:886-897.

Benchaar, C., H. V. Petit, R. Berthiaume, T. D. Whyte, and P. Y. Chouinard. 2006b. Effects of dietary addition of essential oils and monensin premix on digestion, ruminal fermentation characteristics, milk production, and milk composition in dairy cows. J. Dairy Sci. 89:4352-4364.

Benchaar, C., Y. Wang, A. V. Chaves, T. A. McAllister, and K. A. Beauchemin. 2007c. Use of plant extracts in ruminant nutrition. 
Pages 465-489 in Advanced in Medicinal Plant Research. S. N Acharya and J. E. Thomas, ed. Research Signpost, Kerala, India.

Busquet, M., S. Calsamiglia, A. Ferret, P. W. Cardozo, and C. Kamel. 2005b. Effects of cinnamaldehyde and garlic oil on rumen microbial fermentation in a dual flow continuous culture. J. Dairy Sci. 88:2508-2516.

Busquet, M., S. Calsamiglia, A. Ferret, and C. Kamel. 2005a. Screening for the effects of natural plant extracts and secondary plant metabolites on rumen microbial fermentation in continuous culture. Anim. Feed Sci. Technol. 123:597-613.

Busquet, M., S. Calsamiglia, A. Ferret, and C. Kamel. 2006. Plant extracts affect in vitro rumen microbial fermentation. J. Dairy Sci. 89:761-771.

Calsamiglia, S., M. Busquet, P. W. Cardozo, L. Castillejos, and A. Ferret. 2007. Essential oils as modifiers of rumen microbial fermentation. J. Dairy Sci. 90:2580-2595.

Calsamiglia, S., L. Castillejos, and M. Busquet. 2006. Alternatives to antimicrobial growth promoters in cattle. Pages $129-167$ in Recent Advances in Animal Nutrition. P. C. Garnsworthy, and J. Wiseman, ed. Nottingham University Press, Nottingham, UK.

Canadian Council on Animal Care. 1993. Guide to the care and use of experimental animals. Volume 1. E. D. Olfert, B. M Cross and A. A. McWilliam, ed. CCAC, Ottawa, Ontario, Canada.

Cardozo, P. W., S. Calsamiglia, A. Ferret, and C. Kamel. 2004 Effects of natural plant extracts on ruminal protein degradation and fermentation profiles in continuous culture. J. Anim. Sci. $82: 3230-3236$

Cardozo, P. W., S. Calsamiglia, A. Ferret, and C. Kamel. 2005. Screening for the effects of natural plant extracts at different $\mathrm{pH}$ on in vitro rumen microbial fermentation of a high-concentrate diet for beef cattle. J. Anim. Sci. 83:2572-2579.

Cardozo, P. W., S. Calsamiglia, A. Ferret, and C. Kamel. 2006. Effects of alfalfa extract, anise, capsicum, and a mixture of cinnamaldehyde and eugenol on ruminal fermentation and protein degradation in beef heifers fed a high-concentrate diet. J. Anim. Sci. 84:28012808.

Carulla, J. E., M. Kreuzer, A. Machmüller, and H. D. Hess. 2005. Supplementation of Acacia mearnsii tannins decreases methanogenesis and urinary nitrogen in forage-fed sheep. Aust. J. Agric. Res. 56:961-970.

Chaves, A. V., K. Stanford, L. Gibson, T. A. McAllister, and C. Benchaar. 2008. Effects of carvacrol and cinnamaldehyde on intake, rumen fermentation, growth performance, and carcass characteristics of growing lambs. Anim. Feed Sci. Technol. 145:396-408

Fraser, G. R., A. V. Chaves, Y. Wang, T. A. McAllister, K. A. Beauchemin, and C. Benchaar. 2007. Assessment of the effects of cinnamon leaf oil on rumen microbial fermentation using two continuous culture systems. J. Dairy Sci. 90:2315-2328.

Goetsch, A. L., and F. N. Owens. 1985. Effects of sarsaponin on digestion and passage rates in cattle fed medium to low concentrates. J. Dairy Sci. 68:2377-2384.

Hagerman, A. E. 1992. Tannin-protein interactions. Pages 236-247 in Phenolic Compounds in Food and Their Effects on Health. I. Analysis, Occurrence, and Chemistry. C. T. Ho, C. Y. Lee, and M. T. Huang, ed. Am. Chem. Soc. Symp. Ser. No. 506. Am. Chem. Soc., Washington, DC.

Hart, K. J., D. R. Yanez-Ruiz, S. M. Duval, N. R. McEwan, and C. J. Newbold. 2007. Plant extracts to manipulate rumen fermentation. Anim. Feed Sci. Technol. doi:10.1016/j.anifeedsci.2007.09.007.

Hristov, A. N., K. L. Grandeen, J. Ropp, and D. Greer. 2004. Effect of Yucca schidigera-based surfactant on ammonia utilization in vitro, and in situ degradability of corn grain. Anim. Feed Sci. Technol. 115:341-355.

Hristov, A. N., M. Ivan, L. Neill, and T. A. McAllister. 2003. A survey of potential bioactive agents for reducing protozoal activity in vitro. Anim. Feed Sci. Technol. 105:163-184.

Hristov, A. N., T. A. McAllister, F. H. Van Herk, K. J. Cheng, C. J. Newbold, and P. R. Cheeke. 1999. Effect of Yucca schidigera on ruminal fermentation and nutrient digestion in heifers. J. Anim. Sci. $77: 2554-2563$.
Hristov, A. N., J. K. Ropp, S. Zaman, and A. Melgar. 2008. Effects of essential oils on in vitro ruminal fermentation and ammonia release. Anim. Feed Sci. Technol. doi:10.1016/j.anifeedsci.2007.09.034.

Hussain, I., and P. R. Cheeke. 1995. Effect of dietary Yucca schidigera extract on rumen and blood profiles of steers fed concentrate or roughage-based diets. Anim. Feed Sci. Technol. 51:213-242.

Makkar, H. P. S. 2003. Effects and fate of tannins in ruminant animals, adaptation to tannins, and strategies to overcome detrimental effects of feeding tannin-rich feeds. Small Rumin. Res. 49:241256.

Makkar, H. P. S., K. Becker, H. J. Abel, and C. Szegletti. 1995 Degradation of condensed tannins by rumen microbes exposed to quebracho tannins (QT) in rumen simulation technique (RUSITEC) and effects of QT on fermentation processes in the RUSITEC. J. Sci. Food Agric. 69:495-500.

Makkar, H. P. S., S. Sen, M. Blummel, and K. Becker. 1998. Effects of fractions containing saponins from Yucca schidigera, Quillaja saponaria, and Acacia auriculoformis on rumen fermentation. J. Agric. Food Chem. 46:4324-4328.

McAllister, T. A., T. Martinez, H. D. Bae, A. D. Muir, L. J. Yanke, and G. A. Gones. 2005. Characterization of condensed tannins purified from legume forages: Chromophore production, protein precipitation and inhibitory effects on cellulose digestion. J. Chem. Ecol. 31:2049-2068.

McDonald, I. 1981. A revised model for the estimation of protein degradability in the rumen. J. Agric. Sci. (Camb.) 96:251-252.

Molero, R., M. Ibara, S. Calsamiglia, A. Ferret, and R. Losa. 2004. Effects of a specific blend of essential oil compounds on dry matter and crude protein degradability in heifers fed diets with different forage to concentrate ratios. Anim. Feed Sci. Technol. 114:91104.

National Research Council. 2001. Nutrient Requirements of Dairy Cattle. 7th rev. ed. National Academy Press, Washington, DC.

Newbold, C. J., S. M. El Hassan, J. Wang, M. E. Ortega, and R. J. Wallace. 1997. Influence of foliage from African multipurpose trees on activity of rumen protozoa and bacteria. Br. J. Nutr. $78: 237-249$.

Newbold, C. J., F. M. McIntosh, P. Williams, R. Losa, and R. J. Wallace. 2004. Effects of a specific blend of essential oil compounds on rumen fermentation. Anim. Feed Sci. Technol. 114:105-112.

Ogimoto, K., and S. Imai. 1981. Techniques of rumen microbiology. Page 185 in Atlas of Rumen Microbiology. Japan Scientific Societies Press, Tokyo.

Pen, B., C. Sar, B. Mwenya, K. Kuwaki, R. Morikawa, and J. Takahashi. 2006a. Effects of Yucca schidigera and Quillaja saponaria extracts on in vitro ruminal fermentation and methane emission. Anim. Feed Sci. Technol. 129:175-186.

Pen, B., K. Takaura, S. Yamaguchi, R. Asa, and J. Takahashi. 2006b. Effects of Yucca schidigera and Quillaja saponaria with or without ß 1-4 galacto-oligosaccharides on ruminal fermentation, methane production and nitrogen utilization in sheep. Anim. Feed Sci. Technol. 138:75-88.

Sliwinski, B. J., C. R. Soliva, A. Machmüller, and M. Kreuzer. 2002. Efficacy of plant extracts rich in secondary constituents to modify rumen fermentation. Anim. Feed Sci. Technol. 101:101-114.

Teferedegne, B. 2000. New perspectives on the use of tropical plants to improve ruminant nutrition. Proc. Nutr. Soc. 59:209-214.

Valdez, F. R., L. J. Bush, A. L. Goetsch, and F. N. Owens. 1986. Effect of steroidal sapogenins on ruminal fermentation and on production of lactating dairy cows. J. Dairy Sci. 69:1568-1575.

Van Soest, P. J., J. B. Robertson, and B. A. Lewis. 1991. Symposium: Carbohydrate methodology, metabolism and nutritional implications in dairy cattle. Methods for dietary fiber, neutral detergent fiber, and nonstarch polysaccharides in relation to animal nutrition. J. Dairy Sci. 74:3583-3597.

Waghorn, G. C., and I. D. Shelton. 1997. Effect of condensed tannins in Lotus corniculatus on the nutritive value of pasture for sheep. J. Agric. Sci. (Camb.) 128:365-372.

Wallace, R. J., L. Arthaud, and C. J. Newbold. 1994. Influence of Yucca schidigera extract on ruminal ammonia concentrations and 
ruminal microorganisms. Appl. Environ. Microbiol. 60:17621767.

Wang, Y., T. A. McAllister, L. J. Yanke, Z. J. Xu, P. R. Cheeke, and K. J. Cheng. 2000. In vitro effects of steroidal saponins from Yucca schidigera extract on rumen microbial protein synthesis and rumen fermentation. J. Sci. Food Agric. 80:2114-2122.

Weatherburn, M. W. 1967. Phenol-hypochlorite reaction for determination of ammonia. Anal. Chem. 39:971-974.

Wilson, R. C., T. R. Overton, and J. H. Clark. 1998. Effects of Yucca schidigera extract and soluble protein on performance of cows and concentrations of urea nitrogen in plasma and milk. J. Dairy Sci. 81:1022-1027.
Woodward, S. L., G. C. Waghorn, M. J. Ulyatt, and K. R. Lassey. 2001. Early indications that feeding Lotus will reduce methane emission from ruminants. Proc. N.Z. Anim. Prod. 61:23-26.

Wu, Z., M. Sadik, F. T. Sleiman, J. M. Simas, M. Pessarakli, and J. T. Huber. 1994. Influence of yucca extract on ruminal metabolism in cows. J. Anim. Sci. 72:1038-1042.

Yang, W. Z., C. Benchaar, B. N. Ametaj, A. V. Chaves, M. L. He, and T. A. McAllister. 2007. Effects of garlic and juniper berry essential oils on ruminal fermentation and on the site and extent of digestion in lactating cows. J. Dairy Sci. 90:5671-5681. 